\title{
Correction to: The Impact of Executives' Gender, Financial Incentives, and Shareholder Pressure on Corporate Social and Ecological Investments
}

\author{
Jochen Theis $\mathbb{D} \cdot$ Marvin Nipper (D)
}

Published online: 12 January 2022

(C) The Author(s) 2022

\section{Correction to:}

\section{Schmalenbach J Bus Res 2021}

https://doi.org/10.1007/s41471-021-00122-8

Unfortunately the following typesetting errors appeared after the online publication of the article:

- On page 17, Fig. 4: the label of the y axis was missing.

- On page 16, Table 2: error in the top right cell and in the labelling of the first row

The original article has been corrected.

Open Access This article is licensed under a Creative Commons Attribution 4.0 International License, which permits use, sharing, adaptation, distribution and reproduction in any medium or format, as long as you give appropriate credit to the original author(s) and the source, provide a link to the Creative Commons licence, and indicate if changes were made. The images or other third party material in this article are included in the article's Creative Commons licence, unless indicated otherwise in a credit line to the material. If material is not included in the article's Creative Commons licence and your intended use is not permitted by statutory regulation or exceeds the permitted use, you will need to obtain permission directly from the copyright holder. To view a copy of this licence, visit http://creativecommons.org/licenses/by/4. $0 /$.

The online version of the original article can be found under https://doi.org/10.1007/s41471-021$00122-8$

Jochen Theis

University of Southern Denmark, Universitetsparken 1, 6000 Kolding, Denmark

E-Mail: jot@sam.sdu.dk

Marvin Nipper $(\bowtie)$

University of Duisburg-Essen, Lotharstr. 65, 47057 Duisburg, Germany

E-Mail: marvin.nipper@uni-due.de 